\title{
BABEL Y BARROCO: «HABLAR EN LENGUAS» Y OTRAS MANIFESTACIONES TEOLINGÜÍSTICAS ÁUREAS
}

Elena DEL Río PARRA

Georgia State University

\footnotetext{
En la segunda parte se trata de la práctica y modo de exorcizar a los Energúmenos, con sus conjuros y oraciones eficacísimas (Benito R. Noydens, Práctica de exorcistas).
}

El episodio de la torre de Babel, narrado en el undécimo capítulo del Génesis, presentaba el más horrible cuadro de crisis, la mayor pesadilla jamás contada: la fragmentación del lenguaje, instrumento de la unidad y del poder, en infinitos balbuceos y códigos de lenguaje interferentes. No se sabe quién es el narrador, ya que se trata de una de esas obras escritas por el Espíritu Santo a las que frecuentemente se refirió Jorge Luis Borges con el regusto de lo paradójico; se ignora, además, en qué lengua fue capaz de narrarlo antes de que se produjese la fragmentación, si bien se nos dice que diversos pueblos, tal vez poseedores de una lengua universal, contribuyeron a la construcción de la torre ${ }^{1}$.

San Pablo, recreando el episodio, advertía a los corintios en su primera epístola de las nefastas consecuencias que acarrearía una desintegración linguíistica, animándoles a hablar en lenguas sólo para meditar ${ }^{2}$. Esta preocupación debería haber sido ajena al clima vivido en la España de los Siglos de Oro, cuando la hegemonía del castellano, nueva lengua paneuropea, no se veía amenazada por ninguna otra, ni comercial ni demográficamente. Los españoles no tenían necesidad de aprender idiomas ya que los extranjeros, bien por moda,

\footnotetext{
' Esa metáfora se tradujo magistralmente en la Edad de Oro transmutada en las imágenes de Pieter Brueghel «el viejo» y Atanasio Kircher, que la «leen» al modo romano, eltdiendo cualquier tinte mesopotámico.

${ }^{2}$ «Os ruego que tengáis todos concordia; y no haya entre vosotros divisiones, sino que estéis unidos en el mismo pensamiento y en el mismo parecer» (1:10). "porque el que habla lenguas no habla para los hombres, sino para Dios, ya que nadie lo entiende, aunque en espíritu hable misterios» (14:2).
}

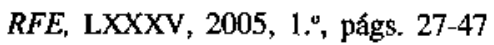


bien por intereses diplomáticos o comerciales, se preocupaban por aprender nociones básicas de la lengua del Imperio y, como indica Antonio Alatorre,

Es notable el contraste entre semejante proliferación de gramáticas españolas para uso de extranjeros y la falta de interés de los españoles por las lenguas extranjeras, salvo la italiana, que muchísimos conocían por la simple lectura, sin necesidad de manuales. Rarísimos españoles de estos siglos supieron hablar alemán, holandés, inglés y aun francés. ¿Por qué iban a aprender lenguas extranjeras, si los extranjeros se encargaban de aprender la castellana? $?^{3}$.

Pero, a pesar de que esta supremacía debería haber servido para crear un clima de estabilidad y despreocupación, el debate sobre las lenguas desde el punto de vista de su producción y uso religioso no hace sino proliferar en España: desde las primeras consideraciones sobre la traducción de la Biblia en $1502^{4}$, el asunto encuentra ramificaciones teolinguísticas y estéticas que se extienden a lo largo de los Siglos de Oro y que conforman un panorama a la vez atrayente e inquietante. El castellano, lengua de comercio y de viaje, se impuso gradualmente como idioma legítimo de culto religioso en la Penúnsula. No obstante, se enfrentaba a constantes amenazas, algunas provenientes de aquellos opuestos al catolicismo y otras nacidas en el seno de la Iglesia misma. Como veremos, cualquier intento de superponer lengua y teología en los Siglos de Oro tiene como resultado, no lenguas perfectas dadas por Dios al catolicismo para su propagación como la única religión verdadera, sino situaciones conflictivas de pronunciación y traducción interferentes. De ese modo, el discurso sobre la escisión que divide todas las lenguas habladas en la cristiandad de las heréticas encuentra un cauce paralelo en las múltiples expresiones de lo demoníaco: los idiomas hablados en territorio cristiano son superiores a cualquier lengua paga-

- na, pero son utilizados por el maligno para sus propios y engañosos fines de tal modo que, apropiándose de lenguajes ortodoxos como el castellano, el diablo los manipula en su propio beneficio poniendo en serios aprietos al estamento clerical, que debe luchar para poner coto a estos desmanes linguísticos. Si los ángeles se comunicaban sin necesidad de lenguaje, el demonio se apropia de los códigos de comunicación católicos para sembrar la confusión.

Lutero y Erasmo coincidían con los católicos, especialmente los místicos, en la eficacia de la oración mental, y el primero consideraba, además, que el único credo válido era la palabra de Dios predicada por su hijo, por lo que creía

3 «El apogeo del castellano», Los 1001 años de la lengua española, Madrid, Fondo de Cultura Económica, 2003, págs. 285-286.

${ }^{4}$ La fecha de edictón del Nuevo Testamento es 1512-1514 (poniéndose a la venta en 1520), y la del Antiguo Testamento 1515-1517, según indica Mariano Revilla Rico, La Poliglota de Alcalá. Estudio histónico-crítico, Madrid, Imprenta Helénica, 1917, págs. 113 y 38, respectivamente. 
superfluos los rituales de la confesión, el ayuno eucarístico, las bulas y la ceremonia de la misa. Este intimismo extendido a los protocolos eclesiásticos no hizo sino sumarse a las dilatadísimas reflexiones en torno a la Vulgata y fue rechazado por el catolicismo oficial, motivo de frecuentes disputas teológicas y asunto de diversos procesos de fe en los que los jueces no se preocupaban por hacer distinción en el veredicto. El 21 de enero de 1624 Benito Ferrer, hebreo por vía materna, se fingió sacerdote, le arrebató al oficiante la sagrada forma y la despedazó durante de la misa. Fue condenado al brasero por «expulso de dos religiones Descalzas, hereje calvinista y luterano» ${ }^{5}$. Análogamente, las anónimas Noticias de Madrid refieren el caso de doña Ana de Enríquez de Cisneros, la «santa de Guadalajara», cristiana vieja, beata presa de falsas ilusiones, que comulgaba varias veces al día blasfemando frente al crucifijo y tenía pacto con el Demonio. Finalmente fue condenada por «hereje arriana, calvinista, mahometana) ${ }^{6}$. Todas las variedades del protestantismo, desde el férreo plan de Calvino al más laxo de Arrio, vienen a sumarse a' lo mahometano como sinónimos de herejía sin necesidad de matices en una suma de falsos credos que no hacen más que agravar las culpas y las penas en proporción directa.

Si la destrucción de la sagrada forma y las visiones ilusorias eran hechos con serias implicaciones de fe, a ellos hay que sumar la interferencia de códigos que amenazan el castellano como lengua de expresión religiosa. Si consideramos el fenómeno Barroco como caso práctico de la metáfora babélica, donde la acumulación es un rasgo distintivo, ¿qué pasaría si nuevas lenguas, encontradas o inventadas, tuviesen que convivir en un espacio de poder máximo? ¿Qué ocurre cuando el lenguaje dominante se torna defectuoso o cae en bocas incompetentes? El resultado de ese «laboratorio» ha inquietado a linguistas y estudiosos de la cultura en sus varias vertientes ya que, en lugar de la fragmentación y la destrucción vaticinada por San Pablo, se producen fenómenos muy distintos y, a la vez, muy curiosos.

De todos ellos, tal vez la poliglosia haya sido el más atendido por los estudiosos de la literatura, entre los que cabe contar a Diana de Armas Wilson, quien observa cómo ficticios traductores políglotas son capaces de mediar como buenamente pueden entre las doce lenguas presentes en el Persiles ${ }^{7}$, conformando lo que Aurora Egido denominó «la idea utópica de una monar-

\footnotetext{
${ }^{5}$ Antonio León Pinelo, Anales de Madrid (desde el año 447 al de 1658), transcripción, notas y cronología de Pedro Fernández Martín, Madrid, Instituto de Estudios Madrileños, 1971, págs. 260-261.

${ }^{6}$ Noticias de Madrid (1621-1627), ed, de Ángel González, Palencia, Madrid, Ayuntamiento de Madrid, 1942, pág. 3.

${ }^{7}$ «Speaking in Tongues: Cervantes's Translator Transila», «Never-ending Adventure»: Studies in Medieval and Early Modern Spanish Literature in Honor of Peter N. Dunn, Newark, Juan de la Cuesta, 2002, pág. 236.
} 
quía universal cristiana» donde, idílicamente, el español serviría como lengua de trabajo y comercio, de fe, de civilización y de convivencia ${ }^{8}$. La facultad de la poliglosia, llamada «don de lenguas», muy presente también en los libros de caballerías, va asociada frecuentemente a la traducción e interpretación, facilitando la diplomacia entre diferentes culturas. Esta es, idealmente, la situación propuesta en la «Babel» americana conformada por más de treinta lenguas, que representa la literalización de la metáfora bíblica y requiere de la presencia de traductores desde los primeros momentos de la conquista, por enclavarse en territorios sin mapa. Es por ello que Cristóbal Colón verdaderamente descubre monstruos, pero son ilegibles y no se corresponden a los clasificados por los bestiarios medievales porque su forma es Ia de una inmensa variedad de códigos no conocidos por los misioneros quienes, carentes del don divino de lenguas, han de servirse de traductores que gradualmente se vuelven competentes en el arte de la traición.

En 1594 el agustino fray Luis López de Solís disponía en el Sínodo de Quito que fuesen

examinados los beneficiados que entran en el sínodo en la lengua de los indios que tienen a cargo. Por cuanto estamos informados que la mayor parte de los beneficiados que asisten en el sínodo no saben la lengua, lo cual sería notable falta; pues con ella han de administrar los santos sacramentos ${ }^{9}$.

Dos años más tarde publicó las conclusiones del Sínodo de Loja, en cuya constitución 21 se declaraba que «Hasta ahora se ha enseñado la doctrina a los indios en dos lenguas, primero en la española y después en la materna, pero es cosa superflua y muy prolija, pues ninguno está obligado a saberlo más que en una lengua, por lo cual de aquí en adelante se enseñe en la lengua materna». No sospechaba el Provincial que el delegar la catequesis en las lenguas indígenas daría lugar a una serie de confusiones propiciadas por la interferencia de códigos. Dos eran las soluciones posibles para poner fin a la confusión de lenguas, situación que iba en detrimento de la fe: la primera, fomentada por López de Solís, pasaba por imponer a los curas de almas el aprendizaje de la Iengua de los indígenas que tenían a su cargo ${ }^{10}$. La posición privilegiada de un

\footnotetext{
${ }^{8}$ «Las voces del Persiles», «Bon compaño, jura dil»? El encuentro de moros, judíos y cristianos en la obra cervantina, ed. de Caroline Schmauser y Monika Walter, Madrid y Francfort, Iberoamericana-Vervuert, 1998, pág. 114.

${ }^{9}$ Sinodos de Quito 1594 y Loja 1596 por fray Luis López de Solls, ed. de Femando Campo del Pozo y Félix Carmona Moreno, Madrid, Revista Agustiniana, 1996, cap. 86.

${ }^{10}$ Esta es una situación ideal cuya propuesta se reitera ya entrado el siglo XIX: «Yo, señor, le respondí, he pensado ser clérigo. Muy bien me parece, me dijo mi padre; pero no tienes capellanía, y en este caso, es menester que estudies algún idioma de los indios, como mexicano, otomí, tarasco, matzagua u otro para que te destines de vicario y administres a aquelios pobres los santos sacramentos en los pueblos» (José Joaquín Fernández de Lizardi, El Periquillo Sarniento [1816], ed. de Carmen Ruiz Barrionuevo, Madrid, Cátedra, 1997, t. I, cap. IX).
} 
clérigo docto en lenguas indígenas evitaría la dependencia de asistentes y traductores, no siempre diligentes ni en traducir ni en guardar el secreto de confesión. Este proyecto, no obstante, seguía sin obtener resultados en 1775 , si hemos de creer las palabras de Alonso Carrió de la Vandera:

Los curas beneméritos se hacen regularmente de unos hombres sabios en la escritura sagrada, pero como por lo general ignoran el idioma de los indios, solicitan para sus ayudantes unos intérpretes, que solamente se ordenaron título de lenguaraces, como se dice vulgarmente, sin más principio que una tosca latinidad y algunas definiciones de escasos casos de moral y lo que la razón natural les dicta. Los curas explican mal el evangelio a los indios porque no entienden bien su idioma, y los ayudantes porque no entienden el evangelio, ni aun la letra del latín». "Yo he observado esto, dije al visitador, en un pueblo en donde todos los indios decían en el padre nuestro: Hágase, Señor, tu voluntad, ast en el cielo como en la tierra. Don Miguel Sierralta y su esposa, que son los mejores lenguaraces que hay en la villa de Guancavélica, me aseguraron haber oído en un solo sermón que cierto cura predicó los indios de su pueblo más de veinte herejías y errores crasos ${ }^{11}$.

Una segunda solución consistía en prescindir de la traducción de catecismos, fórmulas rituales y confesionarios para, progresivamente, imponer a la población indígena el aprendizaje del español, proyecto que, de nuevo, Carió de la Vandera declara fracasado por culpa de los mismos intérpretes quienes, viendo peligrar su oficio, fomentan la segregación linguística en beneficio propio, saboteando cualquier posibilidad de bilingüismo y reservándose la poliglosia como derecho adquirido:

La primera causa que se hace a los señores curas es la de no poner todo su empeño en introducir en sus doctrinas la lengua castellana, por los medios fáciles que propuse [...] Los ayudantes de los señores curas, que por lo general se ordenaron a título de lengua, y que tratan más con los indios, no quieren que éstos hablen otro idioma, y [a] algunos que quieren explicarse en castellano, los reprenden tratándolos de bachilleres y letrados, como me confesó el actual y dignísimo obispo de $\mathrm{La} \mathrm{Paz}^{12}$.

$\mathrm{La}$ instrucción del catecismo en las diferentes lenguas indígenas no era el único problema al que habían de enfrentarse los curas de almas en territorio americano. El Farol indiano ${ }^{13}$ de fray Manuel Pérez nos recuerda que, a co-

$"$ El lazarillo de ciegos caminantes desde Buenos Aires, hasta Lima con sus itinerarios según la más puntual observación, con algunas noticias útiles a los nuevos comerciantes que tratan en mulas, Buenos Aires, Ediciones Argentinas Solar, 1942, cap. XVIII.

12 Ed. cit., cap. XIX.

${ }^{13}$ Farol indiano, y gufa de curas de indios. Suma de los cinco sacramentos que administran los ministros evangélicos en esta América. Con todos los casos morales que suceden entre indios, deducidos de los más clásicos autores, y amoldados a las costumbres, y privilegios de los naturales, México, Francisco de Rivera Calderón, 1713. Esta obra fue objeto de censura de la pluma de los jesuitas José de Porras y Miguel de Castilla en 1712, según indica M.* Águeda 
mienzos del siglo XVII, la validez de los sacramentos administrados en traducción sigue siendo un tema espinoso de discusión teolingüística. El tratado se imprime con cinco «pareceres» adjuntos que discuten la proposición que arguye la carencia de equivalente posible en lengua mexicana para traducir la fórmula ritual instituida por Jesucristo. Fray Manuel Pérez sostiene que «bautizan» ha de ser necesariamente traducido como «echar agua en la cabeza», y ello significa la exclusión de cualquier otra parte del cuerpo, cuando en realidad el ritual del bautismo permite imponer el sacramento en el pie o mano de un individuo que está naciendo.

Estos debates sobre la traducción de la fe no eran privativos del espacio americano: dentro de la Península se imprimen cartillas doctrinales en vasco y catalán en 1602 y 1636, respectivamente; así mismo, se manda predicar en estas lenguas, manteniendo los ritos sacramentales en latín ${ }^{14}$. La inexistente poliglosia, ajena al utópico paisaje cervantino, da lugar a constantes problemas entre los que se encuentran casós de manipulación linguística por parte de algunos sacerdotes, como refiere Martín Brezmes Díez de Prado:

Y esto, a mi parecer, se explica con un ejemplo que hasta ahora no he leído en autor alguno, pero es muy claro: demos que un confesor en la confesión provocase a deshonestidad a una penitente en lengua que ella no entendía, pero que se lo dijese de manera que ella aprendiese las palabras en latín, v. gr. y el confesor le dijese que se las decía para que fuese a un gramático que después se las explicase. Este tal a la verdad solicitó en la confesión y se ha de denunciar ${ }^{15}$.

Otro fenómeno lingüístico presente en la tradición cristiana es la glosolalia, más conocida como «hablar en lenguas» o, recurriendo a un anglicismo, como «jerga neológica», usualmente en un código inventado o no reconocible por el receptor. Estas palabras sin significado o con un significado no determinado guardan ciertas normas gramaticales que permiten clasificarla como lenguaje ${ }^{16}$

Méndez, en Secretos del Oficio. Avatares de la Inquisición Novohispana, México, El Colegio de México, Universidad Nacional Autónoma de México, 2001, pág. 150.

14 Antonio Domínguez Ortiz, «Aspectos sociales de la vida eclesiástica en los siglos XVII y Xvin», Historia de la Iglesia en España, Madrid, Biblioteca de Autores Cristianos, 1979, t. IV, pág. 15. El mismo latín era muchas veces deficiente, por lo que es crucial averiguar si el balbuceo produce una variación accidental que no altera el sentido del sacramento, o si por el contrario ja inserción de una voz subjuntiva u optativa provoca una modificación sustancial y lo hace írrito, como explica Pablo Ramón en su Cartilla y explicación de los rudimentos de la Teología moral, Madrid, Imprenta Real, 1688, págs. 79-80.

is Teatro moral dividido en dos partes. En la primera se trata de las cuarenta y cinco proposiciones que condenó Alejandro VII en dos Decretos. En la segunda se trata de las sesenta y cinco proposiciones que condeno linocencio XI en otro decreto, Salamanca, Gregorio Ortiz Gallardo y Aponte, 1685, pág. 40.

16 Para dichas características, véase el clásico estudio de Feliciana Goodman, quien prefiere interpretar estos patrones como fenómenos aberrantes productos del trance, más que como lent- 
y, contrariamente a lo que podría creerse, no son un síntoma de posesión diabólica sino uno de los carismas reconocidos por la Iglesia como signos divinos. La facultad de expresarse en un lenguaje distinto al propio se traduce en el ritual del trance místico, las bíblicas «lenguas de fuego» que en el Pentecostés permitieron a los apóstoles manifestarse en idiomas no aprendidos (Hechos 2:1-11) ${ }^{17}$ y de cuya interpretación errónea se sorprenderá el propio Erasmo de Rotterdam:

Primeramente, los cristianos convienen poco más menos con los platónicos en que el alma está oculta y ligada por los vínculos corporales y que esta grosería le impide contemplar y gozar las cosas verdaderas. Por ello se define la filosofía como meditación de la muerte, porque, merced a ella, la mente se separa de las cosas visibles y corpóreas, que es lo mismo que hace la muerte. De este modo, en tanto cuanto el espíritu hace uso discreto de los órganos del cuerpo, se le llama sensato, pero cuando, rotos estos vínculos, trata de procurarse la libertad, como si proyectase la fuga de la cárcel, se le califica de loco. Y si ello acontece por enfermedad o deficiencia del organismo, no hay quien discrepe de que ello es locura. $Y$, sin embargo, vemos a tal especie de hombres predecir las cosas futuras, y saber lenguas y letras que hasta entonces nunca habían aprendido, y presentar en sí algo que es absolutamente divino. No cabe dudar de que ello procede de que la mente, al estar algo más libre del contacto del cuerpo, empieza a poner por obra su facultad natural. La misma causa, según creo, debe de tener el que a los moribundos les ocurra algo parecido, como si dijesen ciertas cosas prodigiosas por inspiración ${ }^{18}$.

Este error de exégesis confunde la prodigiosa glosolalia, don de los elegidos por Dios, con un estado de enajenación mental que frecuentemente se toma por xenoglosia o xenolalia, esto es, la capacidad de hablar en lenguas extranjeras sin previo aprendizaje. Esta es una facultad recurrente en la literatura folkórica, en la que algunos niños hablan con fieras, otros poseen el lenguaje de las aves, y muchos fingen hábilmente con fines lucrativos ideando un «falso Pentecostés». Jerónimo de Barrionuevo da noticia de esta superchería diabólica, cuando en Roma atraparon a un chico que hablaba en lenguas y le sacaron del paladar

un pitillo pegado donde tenía un familiar (demonio que le tiene poseído) que, en quitándoselo, no supo más cosa [...] Dijêronle que quién se lo había

gua propiamente dicha: Speaking in Tongues. A Cross-Cultural Study of Glossolalia, Chicago. University of Chicago Press, 1972.

${ }^{17} \mathrm{El}$ estudio más sistemático al respecto, desde un punto de vista estrictamente lingüístico, es el de William J. Samarin: Tongues of Men and Angels. The religious Language of Pentecostalism, Nueva York, MacMillan, 1972.

${ }^{18}$ Elogio de la locura, prólogo, traducción y notas de Pedro Voltes Bou, Madrid, Espasa Calpe, 2003, cap. LXVI. 
dado. Respondió que un fraile [...] Fueron a buscarle y no lo hallaron [...], con lo que todos creyeron debía de ser otro demonio mayor el que se lo había dado. El pitillo echaron al fuego, que saltó como castaña ${ }^{19}$.

Confundidas xenoglosia y glosolalia como un solo fenómeno de «hablar en lenguas», su percepción es la de un código que tiene que ver con manifestaciones divinas o diabólicas, aunque por lo común levanta sospechas y tiende a apreciarse únicamente como expresión del mal. Es así mismo poco común su valoración como rasgo exótico: la humorística «habla de negros» gongorina y la no menos popular habla indígena sorjuaniana, transformada por la autora en homenaje, pueden catalogarse como una suerte de glosolalia contrahecha, donde el codigo no es identificado por el receptor y pasa por lengua desconocida o semi-reconocible, a pesar de los esfuerzos de los emisores por ser entendidos.

Este «hablar en lenguas» es un fenómeno puramente barroco y babélico, por su espectacularidad y capacidad creativa, y no vano ni estéril como la metáfora bíblica había propuesto. Muy al contrario, su presencia en la literatura teológica es constante y significativa, especialmente en la casuística y en los tratados dirigidos a diversos aspectos de la instrucción del clero, donde se dedican numerosas páginas a debatir la existencia y erradicación de las hablas heterodoxas.

Benito Remigio Noydens explica en su Práctica de exorcistas y ministros de la iglesia que el ritual de expulsión del demonio no es sino un combate dialéctico, ocasionalmente público, acompañado de movimientos y gritos ${ }^{20}$. Es común que el poseso se exprese en otros idiomas, aunque al demonio a veces le cueste domar la lengua de los rústicos: «Y uno de los indicios más verdaderos es el hablar o entender latín, v. $g r$. sin haber estudiado, y tratar sutilísimamente de los altos misterios de la fe y sagrada Escritura, siendo un ignorante» ${ }^{21}$. Ese peligro se acrecienta cuando se habla con la encamación misma del demonio, por lo que en El Periquillo Sarniento se recomienda al cura común

19 Avisos (1654-1658), ed. de Antonio Paz y Melia, Madrid, Biblioteca de Autores Españoles, 1969, 29 de mayo de 1656.

20 Madrid, Andrés García de la Iglesia, 1673. El autor recomienda dejar abierta la iglesia durante un exorcismo para que se convierta en un acto ejemplarizante (pág. 73), y evita mencionar (probablemente para no restar valor a su propio tratado) que la propia devoción de los endemoniados puede hacer que se liberen del demonio, con ayuda de la comunión, hecho que sí declara fray Alonso de la Vega en su Suma llamada silva y práctica del foro interior, Alcalá de Нелагеs, Juan friguez de Lequerica, 1594, libro IV, caso 78. Éste se aloja, según el mismo fray Alonso, «algunas veces en el estómago, otras en el humor» (libro V, caso 678), de gran capacidad por las indicaciones de Jerónimo de Barrionuevo: «le han sacado del cuerpo 14 cuentos, 990.850 legiones de demonios, echando por la boca extraordinarias señales [...] Cada legión tenía su capitán, y se componía de 6.666 soldados [...] $\mathrm{Y}$ aún dicen que estaban holgados, y muy a su placen (ed, cit., 18 de diciembre de 1655).

21 Ed. cit., pág. 13. 
que eluda disputar asuntos teológicos con un hereje para evitar el peligro de enredarse en su discurso:

Pues ahora, supongamos un caso remoto, pero no imposible. Supongamos, digo, que un pobrecito vicario de éstos de que hablamos, o un religioso hebdomadario, o que llaman de misa y olla, tiene con un hereje una disputa acerca de la certeza de nuestra religión, de la justicia de su dogma, de lo divino de sus misterios, de la realidad del cumplimiento de las profecías, de lo evidente de la venida del Mesías, del cómputo de las semanas de Daniel o cosa semejante $[\ldots]$ ¿cómo conocerán sus sofismas? ¿Cómo eludirán sus argumentos? ¿Cómo distinguirán su malicia de la fuerza intrínseca de la razón? ¿Y cómo podrá salir de sus labios la verdad triunfante y con el brillo que le es tan natural? Ello es cierto que si sólo el Ferrer, el Cliquet, el Lárraga u otro sumista de moral semejante fueran bastantes para contrarrestar a los herejes, no sé cómo hubiera salido San Agustín con los maniqueos, San Gerónimo con los donatistas, ni otros santos padres con otras chusmas de herejes y heresiarcas a quienes combatieron y confundieron con brillantez y solidez de argumentos ${ }^{22}$.

Una interrogante todavía más sutil plantea si es pecado hablar con los demonios cuando están en un energúmeno. Aunque al exorcista puede serle difícil determinar quién es su interlocutor en cada momento, fray Alonso de la Vega no parece tener duda en concluir que es pecado venial el hablar con ellos por curiosidad, mientras que será mortal «si hay riesgo de descubrir alguna cosa grave y secreta» ${ }^{23}$. Esta situación no es, naturalmente, posible si la purificación se prolonga durante meses: Marcelino Menéndez Pelayo recuerda el caso ocurrido en el convento de la Encarnación Benita de San Plácido de Ma* drid, donde veinticinco de sus treinta monjas requirieron de tres largos años de exorcismos llevados a cabo por fray Francisco García Calderon ${ }^{24}$.

En determinadas ocasiones el demonio es quien decide whablar en lenguas», haciendo uso de unas facultades poliglóticas no documentadas en la Biblia. En algún caso es incluso autor de coplas amorosas vueltas a lo divino, como cuando una rústica a quien había poseído fue capaz de tocar perfectamente la vihuela y contrahacer los versos «Esclavo soy, pero cuyo / eso no lo diré yo» en: «Esclavo soy, pero cuyo / eso no lo niego yo / que cuyo soy me envio / al infierno, donde estoy / porque dije no era suyo ${ }^{25}$. Para muchos mo-

${ }^{22}$ El Periquillo Samiento, ed. cit., t. I, cap. X.

${ }^{23}$ Ed. cit., libro I, caso 238.

${ }^{24}$ Historia de los heterodoxos españoles. Protestantismo y sectas misticas, Madrid, Consejo Superior de Investigaciones Científicas, 1963, t. IV, pág. 250. Las monjas, en un caso de ilusión colectiva, declararon haberse creído endemoniadas y terminaron por ser restituidas a su estado.

${ }^{25}$ Benito R. Noydens, ed. cit., pág. 15. La fuente de esta cita, presuntamente testimonial, no invalida las múltiples intervenciones del demonio como personaje en obras de ficción, especialmente en la dramaturgia áurea. Una representación visual del ritual del exorcismo la ofrece Juan de Valdés Leal en su óleo «San Ignacio exorcizando a un poseso» (1660-1664, Museo de Bellas Artes de Sevilla). 
ralistas de la rama más comprometida con el cumplimiento de la ortodoxia, la máxima expresión demoníaca es la escritura de libros de caballerías, que consideran como la «antibiblia»:

No es menor el daño que hacen los libros que tratan fábulas en verso. Acerca de lo cual no es poco de llorar la mala aplicación de muchos poetas autores de libros fabulosos y perjudiciales, que no habiéndoles faltado ingenio, erudición, buen estilo y estudio de buenas artes, hayan querido emplear su industria y cuidado en ficciones deshonestas y en cuentos fabulosos para perpetua afrenta suya y daño tan notable de la República [...] y no se contentan con esto los poetas de nuestros tiempos, sino que les parece que tienen licencia para decir blasfemias a cada paso; porque si tratan de sus damas dicen más herejías que dijeron los gentiles, llamando cada cual a la suya unas veces divina, otras veces diosa, y a sus acciones, siendo por la mayor parte profanas y lascivas, les dan atributos soberanos diciendo: «divino donaire, angélicas costumbres, celestiales meneos», y dicen que sus damas son su vida, su alma y su último bien y felicidad ${ }^{26}$.

Estos textos son capaces de entrometerse de tal manera en la conciencia de los jóvenes sacerdotes que sus efectos dañinos son perceptibles muchos años después de su lectura:

Decíame un religioso de mucha virtud y oración que con haber más de veinte años que había leído a Amadís de Gaula y a don Belianís de Grecia (que son dos fuentes de esta ponzoña) le inquietaba tanto algunas veces en la oración y otros ejercicios devotos lo que se acordaba de aquellas fábulas que, si Dios no le tuviera muy de su mano, se viera muchas veces perdido con ellas ${ }^{27}$.

Será Benito J. Feijóo quien, al analizar detenidamente los mecanismos del exorcismo, apunte, no al demonio, sino al propio cura como hábil mediador de la lengua de los posesos, poniendo en evidencia el lucrativo negocio demonológico:

Es así, me dirán, que los gestos y latinajos de que hemos hablado no arguyen posesión, y así los sujetos que no hicieren más que eso no deben creerse energúmenos. Pero oímos de muchos o muchas que, sin haber precedido enseñanza alguna, hablan latín en cualquiera materia con gran despejo y propiedad. Yo confieso que lo oímos, pero niego que lo vemos. Oílo de algunas a quienes pude examinar y de hecho examiné. Pero nunca correspondió el hecho a la noticia. Hablemos con cristiano desengaño. Los mismos exorcistas, como he visto varias veces, son por lo común los autores de esta y otras patrañas. Unos cleriguillos, que no tienen otra cosa de que hacer vanidad, sino de la gracia de conjuradores, son los que ordinariamente imponen

${ }^{26}$ José de Jesús M." [Francisco de Quiroga], Primera parte de las excelencias de la virtud de la castidad y virginidad, Alcalá de Henares, Viuda de Juan Gracián, 1601, págs. 771-775.

${ }^{27}$ José de Jesús M.", ed. cit., pág. 767. 
al público diciendo que a esta o aquella a quien exorcizan oyen hablar mil veces latín muy elegante y aun griego y hebreo si los apuran [...] Con esto representan al público utilísima su ocupación, hacen más respetable y, acaso también más lucroso, el ministerio. En caso que no intervenga el incentivo de la codicia, subsiste el de la vanidad ${ }^{28}$.

El anónimo Tratado de los exorcismos y exorcistas de la Iglesia católica advierte de la escasa eficacia o virtud que «tuvo el corazón del pez que guard6 Tobías el mozo para echar los demonios» y «que la música del arpa de David ni la de otros instrumentos fue eficazmente poderosa para echar de los cuerpos los espíritus inmundos» ${ }^{29}$. Sí se admite que algunas personas poseen facultades especiales: Martín de Castañega, por ejemplo, refiere que los reyes de Francia tienen dotes para curar los «lamparones», esto es, la inflamación de los ganglios ${ }^{30}$, y un médico andaluz, pretendiendo que los monarcas españoles no se quedasen cortos, declaró públicamente que tenían facultades para curar endemoniados ${ }^{31}$. También algunos lugares son famosos por los sucesos en ellos ocurridos, tal y como recoge Antonio León Pinelo en la entrada correspondiente a 1591 donde refiere que la ermita de S. Millán era «de particular devoción para expeler demonios de los cuerpos».

Pero, más allá de la materia, la música, las personas y los lugares, sólo las palabras exactas pronunciadas en el momento preciso harán efectivo el ritual. Es interesante observar que el problema de la verbosidad o nominalismo radjcaba en que su sutileza verbal era tal que olvida la raíz bíblica del conocimiento, centrándolo todo en el sistema, en la propia ciencia del lenguaje. De este modo, no son las fuentes bíblicas ni patrísticas las que resuelven el problema, en este caso la administración de un sacramento o la ejecución de un exorcismo, sino el recurso verbal mismo. Si esta era la protesta de Pedro Martínez de Osma en el siglo Xv, un nuevo verbosismo cobra brío para filtrarse en la época posterior a los logros humanistas. Benito R. Noydens, advirtiendo los riesgos de una palabra mal dicha, se queja de que

pues como las deprecaciones susodichas son algo largas, dejan mucho de ellas, haciendo sus síncopas y vaga de tres o cuatro silabas, y algunas veces de otras tantas dicciones juntas [...] muchas veces sucede hacerse la síncopa en las dichas palabras esenciales y dejan de decir lo esencial para la verdad del sacramento, $y$ vase el penitente sin ser legítimamente absuelto ${ }^{32}$.

\footnotetext{
${ }^{28}$ Teatro Critico Universal, Madrid, Pedro Marín, 1739, t. VIII, discurso VI, «Demoníacos», \& III.

${ }^{29}$ Biblioteca de la Universidad de Sevilla, ms. 332-003, [16?], \$18 y \$19, respectivamente.

${ }^{30}$ Tratado muy sutil y bien fundado de las supersticiones, hechicerfas y vanos conjuros y abusiones [...] y de la posibilidad y remedio de ellas, Logroño, Miguel de Eguía, 1529, cap. XIII.

${ }^{31}$ Jerónimo de Barrionuevo, ed. cit., 30 de septiembre de 1654.

${ }^{32}$ Ed. cit., págs. $259-260$.
} 
En pleno momento barroco, la fórmula ritual demanda como requisito esencial no sólo la pronunciación de las palabras correctas, sino el tiempo preciso de su dicción, que debe ser cuidadosamente sincronizada:

uno puede bautizar a muchos, aspersione, y muchos no pueden bautizar a uno, si no fuese que todos juntos comenzasen y acabasen de decir la forma de Ego te baptizo; y si uno la acaba antes, aquel bautizó y no los otros. Y así en este caso los otros serán rebautizadores ${ }^{33}$.

Además, cualquier fórmula pierde su eficacia si no es pronunciada, por ello la comunicación con un interlocutor mudo presenta problemas, como en el caso que plantea «Si al que en el artículo de la muerte ha perdido el habla y no puede confesar, sino solamente muestra muchas señales de contrición como golpes en el pecho o levantar las manos al cielo, si con ellas se le puede absolver de pecados». Aunque algunas opiniones responden negativamente, fray Alonso de la Vega llega a la conclusión de que es posible confesar por señales, dotando al gesto de intención comunicativa y transformando al sacerdote en intérprete de aspavientos in extremis ${ }^{34}$. Fray Juan Enríquez lleva más allá las posibilidades del silencio al admitir que pueden callarse en confesión algunos pecados mortales, siendo lícita la absolución general «si hay un mudo que quiere confesarse y no hay confesor que lo entienda por señas» ${ }^{35}$.

En el extremo opuesto del silencio, algunos téblogos son descritos como auténticos endemoniados. Dispuestos a defender su postura a ultranza, se afanan tanto en las explicaciones que llegan a perder el lenguaje, en una especie de posesión que apuntaría, según cualquier manual de exorcistas, a un más que evidente triunfo del mal:

Hay quienes se encienden tanto, aun cuando se controvierten cosas de levísimo momento, como si peligrase en el combate su honor, su vida y su conciencia. Hunden la aula a gritos, afligen todas sus junturas con violentas contorsiones, vomitan llamas por los ojos, poco les falta para hacer pedazos cátedra y barandilla, con los furiosos golpes de pies y manos [...] que llegan a tal extremo, que ya no sólo los asistentes no los entienden, mas ni aun ellos se entienden a sí mismos [...] Sin duda que en cualquiera ciencia es violentísimo este modo de disputar; pero mucho más que en otras, en la excelsa y serena majestad de la sagrada teología ${ }^{36}$.

\footnotetext{
${ }^{33}$ Francisco Ortiz Lucio, Suma, compendio, recopilacion y manual de todas las sumas, que comúnmente andan, corregida y añadida [...] con muchas adiciones que abrazan todo cuanto dicen las sumas nuevas, Madrid, Luis Sánchez, 1610, pág. 198v.

${ }^{34}$ Ed. cit., libro III, caso 66. $95 \mathrm{v}$.

${ }^{35}$ Cuestiones prácticas de casos morales, Córdoba, Salvador de Cea Tesa, 1646, págs. 95r-

${ }^{36}$ Benito Jerónimo Feijóo y Montenegro, «Abusos de las disputas verbales", en Obras escogidas, Barcelona, Biblioteca Clásica Española, 1884.
} 
Sin duda nos encontramos ante uno de esos momentos en los que la lengua adquiere un «grado cero», el último estadio de un proceso en el que la capacidad de explicación y refinada retórica se fragmenta en aullidos incomprensibles. Esta crisis del lenguaje se encarna en el demonio, que se manifiesta personalmente o a través de sujetos a los que posee consiguiendo que los mismos teólogos pierdan su facultad más preciada.

La incapacidad comunicativa encuentra su trasunto literario más claro en el lenguaje cultivado por Luis de Góngora y sus epígonos, al menos en opinión de sus detractores, quienes pronto encontrarán un punto de comparación teolingüístico fundado en el enrevesamiento gramatical y léxico de una obra que, como explica Andrée Collard, carece de toda utilidad: «La oscuridad de Góngora, que derivaba de la concepción artística misma, era irremediable, perniciosa y ociosa. El error y peligro de la escuela gongorina es, pues, un error moral» ${ }^{37}$ (332). El poeta ya no es el elegido por la divinidad como canal de comunicación profética y reveladora de secretos; por el contrario, Jáuregui y Cascales se quejarán de lo babilónico de las Soledades, sujetas a una extraña «ley» donde se mezclan palabras «vulgares o latinas, griegas o mahometanas», que finalmente son tan oscuras que terminan siendo nada ${ }^{38}$. Esta irritación, en su sentido etimológico, se tomará chanza a ojos de Lope de Vega, quien en el célebre soneto "-Conjúrote, demonio culterano», dramatiza el exorcismo de un hombre que habla en «culto», y cuyas palabras son «borra», relleno sin significado, que inventa las reglas de un nuevo lenguaje sin sentido combinación de su origen polaco y de los excesos de Baco. Para Lope, al menos en su formulación teórica aunque no tanto en su práctica poética, las «coplas castellanas» son equiparables a la poesía italiana y el mejor modo de expresión, claro y sencillo, donde forma y significado se armonizan con el propósito común de combinar arte y pensamiento.

Maldiciones, juramentos, blasfemias, perjurios y herejías son consideradas también productos de la intromisión diabólica en el habla cotidiana, y la Iglesia lucha para erradicar estos exabruptos lingüísticos ${ }^{39}$. Helen Rawlings indica que el $68^{\prime} 6 \%$ de los casos de herejía menor vistos por el tribunal de la Inquisición de Toledo entre 1551 y 1555 fueron por blasfemia, reduciéndose ésta al $19 \%$ entre 1596 y $1600^{40}$. Según el célebre fray Domingo de Soto las «blasfe-

${ }^{37}$ «La «herejía» de Góngora», Hispanic Review 36, $\mathrm{n}^{\circ} 4$ (oct. 1968), pág. 332.

${ }^{38}$ Juan de Jâuregui, Antídoto contra la pestilente poesía de las Soledades [1614], ed. de Eunice Joiner Gates, México, El Colegio de México, 1960, \& 34.

${ }^{39}$ El decir palabras deshonestas por delectación era considerado por algunos teólogos pecado mortal, pero para hacer reír o por decir algún dicho agudo es venial (Juan Enríguez, ed. cit., pág. 42r). Ello no resultaba en ningún caso un agravio a ta fe, ya que iban dirigidas contra personas y no comprometían su vida poniéndolas como testigos.

${ }^{40}$ Church, Religion and Society in Early Modem Spain, Hampshire y Nueva York, Palgrave, 2002, pág. 83. 
mias españolas» son «no creo en tal», «descreo de tal», «reniego de tal», «pese a tal» $\mathrm{y}$ «por vida de tal» ${ }^{41}$. La blasfemia es peor que el perjurio, pero hay diferencias de matiz entre diversas expresiones: «voto a tal» no es una expresión blasfema, pero sí más grave que juramento ${ }^{42}$, mientras que «cuerpo de tal» o «fe de Dios» frisan con blasfemia y «como Dios es verdad» o «como nació de nuestra señora, así es verdad lo que digo» lo son propiamente. Además de las penas del infierno, el infractor incurría en castigos civiles entre los que se contaban treinta días de cárcel, un quintar de dientes o «cortarle un poco de la lengua» ${ }^{43}$. Pedro Galindo se queja no sólo de los ociosos vagabundos que se entregan a las tablas de juego, sino del ruido que hace durante los oficios divinos «la música desconcertada de las maldiciones, juramentos, porvidas y aun blasfemias que suelen acompañar a estos juegos y jugadores, con otros lenguajes feos y sucios, introducidos ya aun entre gente de golilla» ${ }^{44}$.

Todas estas expresiones malsonantes a voz en grito podían ir acompañadas de acciones agravantes, puestó que la blasfemia no sólo se cometía por palabra, sino también por pensamiento, por escrito y por acciones tales como escupir al cielo, rechinar los dientes, querer poner las manos en el cielo, pisar y hollar objetos o vestimenta sagrada ${ }^{45}$. La «blasfemia de obra» puede ser fácilmente confundida con una herejía mayor ${ }^{46}$, de la cual se distingue únicamente por la intención del pecador y que un confesor ha de saber diferenciar:

en una ciudad de Andalucía, habiendo herido a un hombre furioso a otro con una imagen de Cristo crucificado hasta hacerla pedazos, se le preguntó a este hombre si entendió que hacía bien o mal en hacer aquel desacato a la irnagen de Jesucristo; y respondió que siempre entendió que aquello era muy malo y abominable. De modo que este hombre, si dijese que en aquello ha-

${ }^{41}$ Summa de la doctrina christiana compilada [...] por Fray Domingo de Soto de la Orden de Sancto Domingo, Valencia, Viuda de Ioan Mey Flandro, 1557, pág. 45. Dichas expresiones son frecuentes no sólo en el habla sino en la literatura. Algo más usuales en géneros como la picaresca y la celestinesca, no están ausentes, sin embargo, en los escritos de Antonio de Torquemada o Antonio de Guevara,

${ }^{42}$ Domingo de Soto, ed. cit., pág. 56.

${ }^{43}$ Domingo de Soto, ed. cit., pág. 61.

44 Verdades morales en que se reprehenden y condenan los trajes vanos, Madrid, Francisco Sanz, 1678, pág. 161.

45 Andrés de San José, Crisol teologico y asamblea alfabética catslica de toda la teología moral, con [...] las ciento y cuarenta y una proposiciones condenadas por (...] Alexandro VII, Inocencio XI y Alexandro VIII [...] Tomo primero, Madrid, Antonio González de Reyes, 1695 . pág. 73.

46 Nótese que los descomulgados por herejía no son sólo los herejes, sino también sus encubridores, las autoridades que no inquieren diligenternente en la herejía, los que se niegan a prender y castigar al hereje probado y todos los que «impiden directa o indirectamente la sentencia o se oponen a los inquisidores y obispos en esta causa» (Antonio Escobar y Mendoza, Examen y prúctica de confesores y penitentes, en todas las materias de la teología moral, Valladolid, María de Quiñones, 1650, pág. 72). 
bía hecho bien, sería herejía [...] pero como dijo que era malo fue condenado por blasfemo de obra a seis años de galeras ${ }^{47}$.

Si la blasfemia era grave, el juramento se consideraba un pecado todavía mayor «que dar una puñalada a un hombre en medio de esa plaza y dejarlo frío a vuestros pies [...] que si hubiera estado en un camino aguardando para quitar la vida a cien hombre, o si hubiera dado ponzoña o bebedizos a cien hombres y quitádoles con esto la vidas ${ }^{48}$. Tratados como el de Domingo de Soto se esfuerzan en erradicar la costumbre de jurar, además de explicar sus efectos nocivos: «porque como el nombre sea la voz por donde las cosas se significan, y por ende sea como una imagen de las mismas cosas, el mismo honor y alabanza que se debe a las cosas se debe también al nombre» ${ }^{49}$. Por ello se considera especialmente grave jurar por miembros de Dios como la cabeza, la sangre, el hígado, «y aun en algún reino de España por otros miembros vergonzosos de nombrar» ${ }^{50}$.

Fray Juan Enríquez especifica en sus Cuestiones morales que la intención del sujeto es esencial para determinar la gravedad del pecado: «maldición material es la cometida con la boca pero no con el corazón; maldición formal es la que se dice de corazón deseando que se cumpla». Además, «Cuando una persona tiene gran costumbre de maldecir a otros, encolerizándose demasiadamente y mordiendo la tierra y haciendo otras descomposturas semejantes [...] peca mortalmente», aunque si a todos estos gestos no acompaña un deseo de que la maldición se cumpla el pecado será venial, con una salvedad importante debida a tecnicismos de la confesión:

Advierto a los confesores que cuando encuentran gente que tiene esta costumbre de maldecir, y no con deseo de que la maldición comprehenda, que les pregunte si entienden que esto no es pecado mortal, sino venial. Porque podrá ser que estas personas estén persuadidas a que es pecado mortal y, así, pecarán mortalmente con la ignorancia. Pues es cierto que todas las cosas que se hacen con este dictamen [...] pecan mortalmente ${ }^{51}$.

\footnotetext{
${ }^{47}$ Enríquez, ed. cit., págs. 11v-12r.

${ }^{48}$ Alonso de Vascones, Destierro de ignorancias y aviso de penitentes (...) y pictima del alma y arte de ayudar a bien morir, Madrid, Imprenta Real, 1663, pág. 83. Miguel de Cervantes lo considera un simple recurso retórico de persuasión: «Cosas y casos suceden en el mundo que, si la imaginación, antes de suceder, pudiera hacer que así sucedieran, no acertara a trazarlos y, así, muchos, por la raridad con que acontecen, pasan plaza de apócrifos y no son tenidos tan verdaderos como lo son. $\mathrm{Y}$, así, es menester que les ayuden juramentos $\mathrm{o}$, a lo menos, el buen crédito de quien los cuenta» (Los trabajos de Persiles y Sigismunda, ed. de Florencio Sevilla Arroyo, Madrid, Castalia, 1999, libro III, cap. 16).

49 Ed. cit., pág. 9.

50 Ed. cit., pág. 62. En ocasiones se persiguió civilmente esta costumbre cono en 1655 , cuando las cárceles estaban «llenas de juradores, haciéndolos pagar la pena de dinero y prisión» (Barionuevo, ed. cit., 11 de agosto de 1655).

sı Ed. cit., págs. 39v-40r.
} 
Una de las «reglas de oro» de la teología es que no se puede deshacer un hechizo con otro, sino que debe efectuarse mediante invocaciones de santos, que obrarán mediante el poder de la gracia divina. Con esta afirmación la Iglesia declara tanto la existencia del ritual hechiceril como su eficacia ${ }^{52}$, y hace de la lucha contra estas imposiciones una constante, especialmente cuando amenaza sectores privilegiados del Estado. Ello convierte en tema recurrente el de los reyes hechizados, cuestión que llevó a prisión perpetua al teniente capitán de la Guardia de los arqueros don Antonio de Monfort el 27 de julio de 1623 por haber intentado encantar a Felipe IV con ayuda de una mujer, quien recibió doscientos azotes antes de ser desterrada ${ }^{53}$. Estas amenazas demoníacas serán una constante a partir del primer tercio del siglo XVII, y se afianzarán en la generación siguiente con la convicción de que Carlos II estaba enfermo por haber sido hechizado, teoría que auspició Froilán de Mantilla, catedrático de Alcalá, quien convocaría a fray Mauro Tenda para practicar un exorcismo. Como recreó José Cadalso: «llegaron a volverle fatuo. Le hicieron creer que estaba habitado su cuerpo de muchos espíritus infernales. Le exorcizaron y le hicieron hacer tan extrañas posturas y gestos que, junto con las ceremonias del exorcismo, le acabaron de inutilizans ${ }^{54}$.

Los textos que leen las hechiceras no siempre están escritos con las letras del alfabeto. Pedro Ciruelo refiere una amplia variedad de sortilegios como la geomancia, hidromancia (por las manchas de plomo o cera derretida sobre agua), aerimancia (por los sonidos del aire), piromancia, espatulamancia (adivinar por la espina dorsal de animales muertos), quiromancia, sortiaria, oneiro-

\footnotetext{
${ }^{2}$ Francisco de Vitoria había argüido que existía una magia sobrenatural obra de demonios, aunque la mayoría de los fenómenos eran fingimientos de nigromantes. No se atreve a tanto Cristóbal Suárez de Figueroa, quien distingue dos tipos de magia, ambos verdaderos: la natural y la superșticiosa, obrando la segunda «por invocación de malignos espíritus y es una manifiesta idolatría, prohibida siempre por las repúblicas bien ordenadas" (Varias noticias importantes a la humana comunicación Madrid, Tomás Junta, 1621, pág. 54).

53 Noticias de Madrid, ed. cit., pág. 69. La hechicería es a veces disculpada en escritos teológicos, por ser propia de la cultura popular, y por lo tanto despreciable: «Contra este primer mandamuento son las hechicerías, supersticiones y agüeros [...] advirtiendo que cuando en cualquiera de estos pecados hay pacto o invocación al demonio es caso reservado a la Inquisición [...] Y también advierto que cuando en las supersticiones hay ignorancia, que entre gente sencilla suele haber, se puede algunas veces excusar de pecado mortal, porque en gente semejante es invencible esta ignorancias (Enríquez, ed. cit., pág. 12r). En la mayoría de los procesos inquisitoriales, por el contrario, se reconoce que las hechiceras son mujeres sin ninguna instrucción, pero no por eflo están exentas de culpa ya que sus conocimientos son considerados nocivos, no tanto como por su eficacia real sino por la capacidad de sugestión, ánimo de lucro y mala influencia en la sociedad. Estas dos actitudes, desprecio por las indefensas costumbres del vulgo y persecución por su gran peligro, conviven y mantienen ensalmos y conjuros en la marginalidad.

${ }^{54}$ Defensa de la nación española contra la carta persiana LXXVII de Montesquieu (atrib.), ed., prólogo y notas de Guy Mercadier, Toulouse, France-Iberie Recherche, Université de Toulouse, 1970, pág. 10.
} 
crítica y astrología judiciaria. En todas estas manifestaciones los signos se escriben sobre materia que nada tiene que ver con tinta y papel, conformando lenguajes naturales que la Iglesia tiene por nocivos y reprensibles ${ }^{55}$. Así mismo y como ocurre con las oraciones y letanías ortodoxas, las palabras pronunciadas en la hechicería pueden encontrarse escritas ${ }^{56}$, aunque muchas veces se aprenden ocultamente y forman un corpus de composiciones marginales con características como la repetición y funciones como la philocaptio que permiten considerarlas como un subgénero con identidad propia ${ }^{57}$. Si la misma oralidad descalifica los rituales hechiceriles y hace más difícil rastrearlos, preocu-

35 Reprobación de las supersticiones y hechicertas [1538], edición, introducción y notas de José Luis Herrero Ingelmo, Salamanca, Diputación de Salamanca, 2003. El árbol de las ciencias trazado por Enrique de Villena recoge las sesenta ciencias lícitas y las cuarenta ilícitas dominadas por Virgilio; estas últimas se distinguen por no atender más que a intereses personales: Traducción y glosas de la Eneida, Salamanca, Diputación de Salamanca, 1989, ed. y estudio de Pedro M.* Cátedra, págs. 39-40. Ocasionalmente estas prácticas se tienen por pasatiempo vulgar e inofensivo al ser consideradas manifiestamente falsas para algunos clérigos, cuyo escepticismo les hace renunciar a corregir las malas costumbres: «Mirar las rayas de las manos, preguntar a las gitanas por la buena o mala fortuna o echar alguna suerte [...] no es más que venial, corno también las malas observancias de las doncellas en algunas noches del año, porque de ordinario suelen proceder con ignorancia y buena fe, no teniendo estas cosas por pecađo; pero teniéndolas por ciertas, es mortal. Así también es lícito por el nacimiento o fisionomía de alguno conjeturar su complexión, su inclinación a virtudes o ciencias particulares, su habilidad, salud, enfermedades o cosas semejantes, porque no dependen de su libre albedrio. Más qué burlados se hallan algunos que pretenden por este camino rastrear [...] Pues cuando Ios ojos, la frente y orejas parecen pronosticar grande sabiduría, descubren en los más intolerable ignorancia; y cuando las líneas de las manos podráan ser indicios de la disposición del cuerpo, vemos que en diversas edades del hombre se mudan con 6 l, por engordar o por enflaquecer, o porque hacen tales ejercicios con las manos como parece en los labradores, carpinteros y otros muchos oficios. Es también superstición creer que ha de haber algún mal suceso por derramarse la sal o quebrarse el espejo; por tropezar del pie o salir con el izquierdo; por tratar de casamiento en tales o tales días entre el vulgo, aciagos, etc.» (Benito R. Noydens, Practica del oficio de curas y confesores, Valencia, Claudio Macè, 1652, pág. 11).

56 Por ello, naturalmente, «es pecado tener libros de magia y hechiceria o de herejes» (Alonso de la Vega, ed. cit., libro II, caso 502) y estarán descomulgados «los herejes y los que tienen libros de arte mágica o de los tales herejes" (Alonso de la Vega, ed. cit., libro VI, caso 316). Ello no obsta para encontrarlos en escondites como el descubierto en 1995 en la pacense «Biblioteca de Barcarrota», cuyos fondos incluyen una versión portuguesa de la «oración de la emparedada», el Exorcismo admirabile da disfare ogni sorte di malefici et da l?Jgli es per un devoto religioso composto et novamente stampato (1540), y los comentarios Super Chyromantiam de Tricasio de Mantua a la obra de Bartolomé Cocles de Bolonia (1543). Benito R. Noydens se refiere así mismo a palabras «escritas en pergamino virgen, de figura triangular o redonda» o «sobre unas hostias o en el pan de comer». Altamente sacrílegas considera también determinados gestos «para sanar del mal de ojo, para sacar el sol de la cabeza, etc., y las de otros que para sanar al enfenno de las calenturas le miden la cinturas (Práctica del oficio, ed. cit., pág. 9).

${ }^{57}$ José M. Díz Borque, «Conjuros, oraciones, ensalmos...: Formas marginales de poesía oral en los Siglos de Oro", Bulletin Hispanique, 87, nos 1-2 (en.jun. 1985), págs. 47-87. Al filtro o conjuro amoroso y sus efectos específicos y repercusión literaria dedicó Ana Vian Herrero «El pensamiento mágico en Celestina, "instrumento de lid o contienda"», Celestinesca, 14, 2, 1990, págs. 41-91. 
pa también la reapropiación y adaptación por las hechiceras de oraciones de transmisión escrita, como demuestra el hecho de que las pesquisas en los inteпrogatorios insistan en averiguar «qué pacto hizo con el demonio, si tiene algún error contra la fe, si dijo para el hechizo palabras sagradas y creyó había en ellas virtud para tales efectos, qué daño hizo en personas y en cosas» ${ }^{58}$. Cualquier asimilación de textos eclesiásticos canónicos con fines maléficos era equivalente a profanar el verbo divino, puesto que las palabras válidas y verdaderas eran las autorizadas por la Iglesia católica.

La productividad de la lengua ritual tiene que ver con la eficacia de su uso más que con convenciones estéticas. Por ello el empleo de algunas fórmulas está restringido al estamento clerical, afanado en depurar oraciones transgresoras que modifican las palabras, a veces anulando su eficacia, otras veces potenciando efectos negativos y fines ajenos a la ortodoxia. No obstante, el clérigo ha de competir abiertamente con el conjurador ladrón de palabras y fórmulas por un público deseoso de ser sanado y purificado:

Los conjuradores de malos espíritus que, sin ser aprobados de la Iglesia, hacen exorcismos, suelen ser nigrománticos y hechiceros y obrar por pacto de amistad que tienen con el demonio, encubierta o claramente; que para mejor engañarlos les enseña ciertos conjuros, casi semejantes a los que se usan en la Iglesia [...] Acerca de los que se precian saber conjurar los nublados, el granizo y pedrisco ordenando ciertos conjuros ajenos y diferentes de los que ordena la Iglesia, deben ser muy sospechosos, como nigrománticos y ministros del demonio [...] Y no se puede decir que los hacen los ángeles [...] Solamente los pueden mudar de un lugar a otro [...] y esto no permitiese Dios sino muy raras veces ${ }^{59}$.

A pesar de que cualquier alteración de las fórmulas rituales se tiene por indeseable, palabras procedentes de oraciones y salmos ${ }^{60}$ eran adaptadas para

58 Antonio Escobar y Mendoza, ed. cit., págs. 80-81. El énfasis es nuestro. El contrafactum de ritos es, como demuestra Umberto Eco para el sistema tuliano, una simple alteración de leyes combinatorias donde una simple variación convertiría el sistema en una fábrica de proposiciones heréticas: «ipor qué no concebir una combinación blasfema que hable de una Bonitas que sea Dios Vicioso [...]?» (La búsqueda de la lengua perfecta en la cultura europea, Barcelona, Crítica, 1994, pág. 64).

${ }^{59}$ Benito R. Noydens, Práctica del oficio de curas, ed. cit., págs. 13-14. El énfasis es nuestro. La competencia se extiende tambiér a los ensalmadores y saludadores: «Villalobos señala ałgunos indicios que militan contra el crédito que han cobrado en estos tiempos los saludadores [...] El primero, si no son católicos. E] segundo, si son gente de mal vivir. El tercero, si dicen que pueden entrar sin daño en un horno encendido. El cuarto y último, si suelen con el sopło o saliva matar al que rabia, por que no haga mal a otros, lo cual no es lícito ni hay gracia para ello» (Noydens, Práctica del oficio, ed. cit., págs. 12-13).

(t) Las oraciones, a pesar de no haber sido escritas por el Espíritu Santo, están sancionadas por la Iglesia si se prueba su eficacia petitoria o un origen hagiográfico. Si el uso de una fórmula se consideraba supersticioso, la oración era tachada de conjuro y expulsada del canon, tornándose oral o material de pliego suelto, mientras que si fomentaba la fe se propagaba en devocionarios, novenarios y escapularios cuya sola posesión material se tenf́a por beneficiosa. 
funciones específicas. Pedro Ciruelo, tal vez influido por sus estudios, no dudó en compilar centones de la Biblia, algunas de cuyas frases son de su propio cuño:

Sometimes he presented patchworks of verses as if they were coherent scriptural passages. In a work on plague and its spiritual remedies, Ciruelo summoned the following reference to support his point that plague destroyed human networks: «The impious will cease from uproar and those exhausted in strength shall rest $[\ldots]$ ). The problem is that his quotation does not exist in the Bible, at least not as Ciruelo cited it ${ }^{61}$.

Como vemos, desde la Iglesia misma se componen fórnulas con la misma técnica que las hechiceriles y con igual materia prima en forma de «palabras sagradas», método despreciable del que se quejará Alfonso de Valdés: «Allende de esto, de libros y horas de rezar quité muchas oraciones por idiotas e ignorantes, ordenadas más para sus intereses que para otro respecto, en que hallaba no poca superstición y aun idolatría tan manifiesta que no podía leerlos sin liorars ${ }^{62}$.

No es necesario, por tanto, acudir a la poesía popular ni a los libros de hechiceras para encontrar oraciones no reconocidas por la Iglesia, ya que ésta produce en su propio seno composiciones que, aunque fuera del canon, son rezadas con fe por muchos de sus miembros, especialmente aquellas en forma de conjuros contra las plagas. Uno de los rituales para terminar con los estragos de la langosta mediante remedios espirituales, recogidos en la Práctica de exorcistas de Benito R. Noydens, consistía en hacerles un juicio público que concluía con su expulsión del seno de la Iglesia:

porque hay algunos que suelen descomulgarlas y formar contra ellas cabeza de proceso, con sus procuradores de una y otra parte, para alegar cada uno su derecho, y después de muchas demandas y respuestas fulminan sentencia de descomunión mayor, para que las langostas se aparten de los términos del lugar, como si tuvieran libre albedrío y fuesen capaces de las censuras que ordena la Iglesia ${ }^{63}$.

${ }^{61}$ Lu Ann Homza, Religious Authority in the Spanish Renaissance, Baltimore, Johns Hopkins University Press, 2000, pág. 82.

${ }^{62}$ Dialogo de Mercurio y Carón [1529], ed, de Joseph V. Ricapito, Madrid, Castalia, 1993, pág. 236. El inquisidor Fernando de Valdés suptime en su Indice de 1559 diecisiete horas en romance y diez oraciones.

${ }^{63}$ Ed. cit, pág. 133. Desde su secularidad, el Tratado de las langostas del Alcalde Mayor Juan de Quiñones recomienda pagar los diezmos como método eficaz de evitar las plagas, citando una invasión de moscas gigantes tatuadas con las palabras IRA y DEI en Inglaterra (Tratado de las langostas, muy atil y necesario. En que se tratan cosas de provecho y curiosidad para todos los que profesan letras divinas y humanas y las mayores, Madrid, Luis Sánchez, 1620, pág. 33r). Parafraseando a Bartolomé Cassaneo, recuerda cómo el pueblo se dirigía al juez eclesiástico, se querellaba, se nombraba un fiscal y un procurador que defendiese a las langostas. E! 
Además de la excomunión, algunas obras como el Libro de conjuros de Pedro Jiménez proponen un ritual específico de exorcismo para erradicar la plaga, que mediante oraciones similares a las recogidas en tratados demonológicos exhortan al diablo encarnado en los insectos a salir de la tierra, trasunto del cuerpo humano. Es notoria la división entre clérigos ortodoxos y aquellos considerados supersticiosos que fomentan errores teológicos y falsas fórmulas, como denuncia sin rodeos fray Juan Enríquez: «También se ve aquí la ignorancia de algunos que piensan que las langostas, pulgón y otros animales pueden ser descomulgados, lo cual es ignorancia» ${ }^{64}$.

El estudio de las diversas manifestaciones teológicas de la lengua en el Barroco arroja resultados unívocos: el «habla de Dios» tiene lugar únicamente en forma de visiones, oraciones y expresiones místicas ${ }^{65}$. Cualquier expresión deslindada del canon se percibe como diabólica o, cuanto menos, sospechosa y producto de la superstición y de la ignorancia. La creación teolinguística representa un atentado contra la ortodoxia, bien por la encarnación del diablo en sujetos y animales, bien por hechiceras y miembros de la propia Iglesia a los que utiliza. Satán no sólo se inmiscuye adulterando fórmulas rituales, sino que escribe poemas y libros profanos. Los sacerdotes, por su parte, no aciertan a pronunciar correctamente las fórmulas, los traductores mancillan el sentido recto de las palabras y los fieles adoptan el juramento y la blasfemia como modo común de expresión. Esta Babel, pesadilla de prelados que contemplan cómo otros excomulgan langostas y pierden el control de su propio lenguaje, representa el culmen de la desintegración lingüística de la fe, que en ocasiones se interpreta desde la Iglesia como atentado contra la fe misma. La ortodoxia áurea y la persecución de modos de expresión alternativos no fomenta su proliferación, pero su propia búsqueda y pesquisa tiene como consecuencia el hallazgo de nuevas infracciones de diversa gravedad cuya producción y utilización se oponen a las sancionadas por la Iglesia.

No será hasta otro "momento barroco» cuando reaparecerá la metáfora, secularizada ya en forma de dadá, émulo del ba- (prefijo griego que expresa la desorganización gramatical), bla-bla o balbuceo vanguardista con sus imbricaciones primigenias y subconscientes, cuyas posibilidades tan bien supo explorar Vicente Huidobro. Pero en la España posterior al Renacimiento el lenguaje de la divinidad que aseguraba la revelación y la prosperidad, sueño dorado de

juez pronunciaba la sentencia que las mandaba salir del término dentro de tantos días, bajo pena de excomunión. Quir̃ones especifica que es necesario dirigir un ruego a Dios y un mandato al demonio, ante la inseguridad de quién ha enviado la plaga, y que el esconderse en las casas para pasar desapercibidos hasta que ésta pase de largo tampoco es una medida eficaz.

${ }^{64}$ Ed. cit., pág. 114 .

65 Incluso estos lenguajes arrebatados y devotos, que obrarán a favor en los procesos de santificación de sus autores, fueron en ocasiones incluidos en listas de textos prohibjos por su significado críptico y siempre sujetos a cuidadosa inspeccion. 
toda civilización gloriosa, se ve constantemente amenazado por la pluralidad y acumulación de manifestaciones diabólicas. $\mathrm{Si}$ a través del lenguaje los descubridores tuvieron la oportunidad de emular a Dios y crear la realidad y los místicos pudieron rozar la esencia misma de la divinidad, con el advenimiento de una nueva era barroca el lenguaje teológico ortodoxo alcanza el final de un largo camino de desintegración para morir víctima de la superchería. 